\title{
SULUH
}

JURNAL BIMBINGAN DAN KONSELING

UMP

http: //journal.umpalangkaraya.ac.id/index.php/suluh Volume 4 Nomor 2, Februari 2019 (10-13)

\section{KONSELING KELOMPOK MENGGUNAKAN MUSIK UNTUK MENURUNKAN STRESS BELAJAR PESERTA DIDIK DI SMIA MUHAMIMADIYAH 1 PALANGKA RAYA}

\section{Counseling Group Of Using Music To Reduce Stress In Students Learning SMA Muhammadiyah 1 Palangkaraya}

\section{'Andi Riswandi BP'Wiwit Asmarita}

'Universitas Muhammadiyah palangkaraya, Palangka Raya, Kalimantan Tengah, Indonesia

${ }^{2}$ Universitas Muhammadiyah palangkaraya, Palangka Raya, Kalimantan Tengah, Indonesia

\section{ARTIKEL INFO}

Diterima

Januari 2019

Dipublikasi

Februari 2019

*E-mail:

herunurochman@gmail.com

Orchid:

\section{ABSTRAK}

Penelitian ini bertujuan untuk mengetahui layanan konseling kelompok menggunakan musik untuk menurunkan stress belajar peserta didik. Jenis penelitian yang digunakan adalah pendekatan Mix Method dengan bentuk strategi Eksplanatoris Sekuensial. Populasi dalam penelitian ini adalah seluruh peserta didik di SMA Muhammadiyah I Palangka Raya yang berjumlah 358 orang dengan sampel 7 orang peserta didik yang teridentifikasi memiliki tingkat stress belajar yang tinggi. Data di analisis dengan uji $T$ Test Menggunakan aplikasi Software SPSS versi 22.00. teknik pengumpulan data menggunakan skala stress belajar, wawancara dan dokumentasi. Hasil penelitian menunjukan ketujuh peserta didik yang diberikan treatment mengalami perubahan yang positif antara sebelum diberikan treatment dengan sesudah pemberian treatment yang diketahui dari hasil perbandingan Pre-test - Post-test.

Kata kunci: Konseling Kelompok, Stress Belajar, Musik

Kata kunci: Teknik Menggambar, Emosi Marah Peserta Didik.

\section{ABSTRACT}

This study aims to determine the group counseling services using music to reduce learners' stress. The type of research used is the Mix Method approach with the form of sequential explanatory strategies. The population in this study were all students in Muhammadiyah I High School in Palangka Raya, totaling 358 people with a sample of 7 students who were identified as having high levels of learning stress. The data is analyzed with the $T$ Test using the SPSS software version 22.00. Data collection techniques use scale learning stress, interviews and documentation. The results of the study showed that the seven students who were given treatment experienced positive changes between before being given treatment with after treatment which were known from the results of the comparison of Pre-test-Post-test.Keywords: Group Counseling, Stress Learning, Music

Keywords: Drawing Technique, Angry Emotions of Students. 


\section{PENDAHULUAN}

Pendidikan merupakan proses perubahan tingkah laku yang terjadi pada diri individu maupun masyarakat. $\mathrm{Di}$ dalam pendidikan guru merupakan faktor penting karena dengan mengikuti proses pendidikan yang berlangsung peserta didik dapat berubah menjadi yang lebih baik. Keberhasilan peserta didik juga dipengaruhi oleh pengaruh pendidikan yang positif dengan membimbing serta pemberian pengajaran yang bermutu sehingga terciptanya peserta didik yang unggul dan cerdas.

Menurut Sri Rumini dkk. (2006:16), pendidikan pada hakikatnya merupakan usaha sadar, sengaja, dan bertanggung jawab yang dilakukan oleh seorang pendidik terhadap anak didiknya untuk mencapai tujuan ke arah yang lebih maju.

Dunia pendidikan saat ini memiliki tuntutan yang tinggi terhadap prestasi siswanya. Tuntutan itu kadangkala menjadi penyebab munculnya stres pada peserta didik yang tidak memiliki kesiapan dan kedisiplinan dalam belajar. Belajar merupakan permasalahan yang umum dibicarakan setiap orang terutama yang terlibat dalam dunia pendidikan, menghadapi pelajaran yang berat di sekolah dapat menimbulkan stres pada remaja, terutama bagi remaja sekolah menengah karena mereka mendapat tekanan untuk memperoleh nilai yang baik dan dapat masuk ke universitas favorit. Stres pada remaja juga disebabkan oleh tuntutan dari orangtua dan masyarakat.

Pada umumnya, setiap orang pernah mengalami stres, baik ringan, sedang, maupun berat. Istilah "stres" sering digunakan secara tidak tepat, yakni dipakai untuk menunjuk fenomena "tidak waras". Sebenarnya, stres merupakan istilah yang netral, yakni menunjuk pada hal yang selalu dialami manusia dalam kehidupan seharihari. Secara sederhana, stres dapat didefinisikan sebagai suatu keadaan individu yang terganggu keseimbangannya.

Stress terjadi akibat adanya situasi eksternal atau internal yang memunculkan gangguan dan menuntut individu untuk berespon adaptif.

Smith (Aryani, 2016:13), stress belajar yang dialami siswa terjadi bukan semata-mata berasal dari faktor eksternal (lingkungan sekolah dan orang tua), namun faktor internal juga mempengaruhi timbulnya stres belajar, yaitu bagaimana siswa mempersepsikan sekolah

Salah satu unsur yang perlu diperhatikan konselor dalam melaksanakan inovasi dalam layanan konseling adalah seni kreatif. Berbagai jenis seni kreatif dapar diintegrasikan konselor dalam layanan konseling, salah satunya adalah musik. Musik didefinisikan sebagai pengalaman multikultural yang universal yang dapat berfungsi sebagai jembatan untuk pengembangan wawasan dan perilaku baru.

Konseling dengan mengintegrasikan musik dapat membantu konseli mengubah suasana hati mereka dengan baik, mengelola stres belajar yang dialami mereka dan mengurangi kecemasan mereka atau membangkitkan emosi mereka, hampir seluruh manusia menyukai musik, apalagi dikalangan para pelajar, diharapkan dengan musik peserta didik dapat mengelola stres belajar yang di alaminya.

Disinilah peran konselor atau guru BK untuk memberikan layanan konseling kelompok yang kiranya mampu untuk mengatasi masalah belajar pada peserta didik. Dengan konseling kelompok diharapkan guru BK mampu membantu dalam menurunkan stres belajar pada peserta didik.

Pasal I Butir 6 yang mengemukakan bahwa konselor adalah pendidik. Pendidik adalah tenaga kependidikan yang berkualifikasi sebagai guru, dosen, konselor, pamong 
belajar, widiaswara, tutor, instruktur, fasilitator, dan sebutan lain yang sesuai dengan kekhususannya, serta berpartisipasi dalam menyelenggarakan pendidikan.

Berdasarkan paparan di atas maka peneliti berusaha membantu peserta didik melalui Layanan Konseling Kelompok Menggunakan Musik Untuk Menurunkan Stress Belajar Peserta Didik di SMA Muhammadiyah I Palangka Raya.

\section{METODE PENELITIAN}

Penelitian ini merupakan penelitian mixed methods, yaitu suatu langkah penelitian dengan menggabungkan dua bentuk pendekatan dalam penelitian, yaitu kuantitatif dan kualitatif. Creswell dan Plano clark (2010: 3I3), menjelaskan mixed methods adalah "that guide the direction of the collection and analysis of data and the mixture of qualitative and quantitative approaches in many phases in the research process". Jadi desain mixed methods digunakan sebagai pedoman dalam mengumpulkan dan menganalisis dengan menggabungkan pendekatan kualitatif dan kuantitatif dalam setiap fase proses penelitian. Dalam metode mixed methods terdapat 3 strategi diantaranya:

\section{Strategi Eksplanatoris Sekuensial}

Merupakan strategi yang cukup populer dalam penelitian metode campuran dan sering kali digunakan oleh para peneliti yang lebih condong dalam proses kuantitatif. Strategi ini diterapkan dengan pengumpulan dan analisis data kuantitatif pada tahap pertama yang diikuti oleh pengumpulan dan analisis data kualitatif pada tahap kedua. Bobot atau prioritas lebih diberikan pada data kuantitatif.

Strategi Eksploratoris Sekuensial.

Strategi ini mirip dengan strategi sebelumnya, hanya tahap pengumpulan data dan analisis datanya saja yang di balik. Strategi eksploratoris sekuensial melibatkan pengumpulan dan analisis data kualitatif pada tahap pertama, yang kemudian diikuti oleh pengumpulan dan analisis data kuantitatif pada tahap kedua yang didasarkan pada hasil-hasil tahap pertama. Bobot utama pada strategi ini ada pada data kualitatif.

Strategi tansformatif sekuensial.

Strategi ini terdiri dari dua tahap pengumpulan data yang berbeda, satu tahap mengikuti tahap lain, seperti halnya dua stratei sekuensial sebelumnya. Strategi transformatif sekuensial merupakan proyek dua-tahap dengan perspektif teoretis tertentu (seperti, gender, ras, teori ilmu sosial).

\section{HASIL DAN PEMBAHASAN}

Berikut ini sajian perbandingan hasil pengukuran tingkat stress peserta didik dalam menurunkan stress belajar, dengan menggunakan skala stress belajar Pre-test dan post-test pada subjek penelitian. Data dari hasil Pre-Test dan Post-Test pada subjek penilitian dilengkapi dengan deskripsi perubahan pada diri peserta didik dari masing-masing peserta didik. Berikut adalah hasil Pre-test dan post-test subjek penelitian. Hasil Pre-test dan Post-test pada subjek penelitian

\begin{tabular}{|l|l|l|l|l|}
\hline $\begin{array}{l}\text { peserta } \\
\text { didik }\end{array}$ & $\begin{array}{l}\text { skor pre- } \\
\text { test }\end{array}$ & kategori & $\begin{array}{l}\text { skor } \\
\text { post-test }\end{array}$ & kategori \\
\hline AR & 182 & sedang & 177 & sedang \\
\hline AN & 196 & sedang & 185 & sedang \\
\hline AW & 195 & sedang & 148 & sedang \\
\hline NA & 183 & sedang & 181 & sedang \\
\hline NS & 204 & sedang & 171 & sedang \\
\hline SW & 185 & sedang & 140 & rendah \\
\hline YI & 192 & sedang & 185 & sedang \\
\hline
\end{tabular}

Berdasarkan data perubahan di atas, maka perubahan tingkat stress belajar pada subjek, secara keseluruhan pada saat pre-test dan post-testdapat dilihat pada grafik berikut ini.

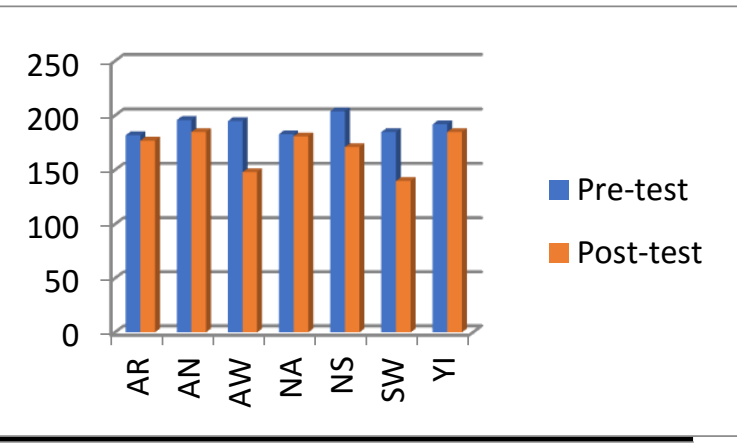


Hasil Pre-Test Dan Post-Test Pada Subjek Penelitian. Berdasarkan hasil skala stress belajar yang dilakukan oleh peneliti, ke 7 orang peserta didik mengalami penurunan tingkat stress belajar seperti yang telah di jelaskan di atas bahwa hasil akhir post-test menunjukkan bahwa ada penurunan dari hasil pre-test masing-masing peserta didik.

\section{KESIMPULAN}

Ada perbedaan tingkat stress belajar pada peserta didik. Hal tersebut didasarkan pada hasil skala post-test menunjukkan bahwa ketujuh peserta didik pada subjek penelitian mengalami penurunan tingkat stress belajar peserta didik sesudah diberikan perlakuan (treatment).

Berdasarkan hasil analisis bahwa layanan konseling kelompok menggunakan musik dapat menurunkan stress belajar peserta didik di kelas XI IPA-I SMA Muhammadiyah I Palangka Raya. Itu artinya layanan konseling kelompok menggunakan musik efektif dalam menurunkan tingkat stress belajar peserta didik kelas XI-IPA I SMA Muhammadiyah I Palangka Raya.

\section{DAFTAR PUSTAKA}

Aryani, F. 2016. Stres Belajar Suatu Pendekatan Dan Intervensi Konseling. Sulawesi Tengah: PT Edukasi Mitra Grafika

Astuti, B. 2012. Modul Konseling Kelompok. Yogyakarta: FIP UNY

Burhan, Bugin. 2010. Analisis Data Penelitian Kualitatif. Jakarta: PT Rajagfindo Persada

Creswell, 2010. Research Design Penelitian Kualitatif, Kuantitatif, Dan Mixed. Yogyakarta: Pustaka Pelajar

Gladding, T. Samuel. 2012. Konseling Profesi yang menyeluruh. Jakarta: PT Indeks

Gunawan, Iman. 20I4. Metode Penelitian Kualitatif Teori Dan Praktek. Jakarta: PT Bumi Aksara
Komalasasi dkk. 20I I. Asesmen Teknik Nontes Dalam Perspektif BK Komprehensif. Jakarta Barat: PT Indeks

Latipun, 2005. Psikologi Konseling. Malang: Universitas Muhammadiyah Malang.

Latipun, 2008. Psikologi Konseling. Malang: Universitas Muhammadiyah Malang.

Nurishan, 20012. Strategi Layanan Bimbingan dan Konseling. Bandung: PT Refika Aditama

Safaria \& saputra, 20I2. Manajemen Emosi. Jakarta: PT Bumi Aksara

Sanjaya, W. 2013. Penelitian Pendidikan: Jenis, Metode, Dan Prosedur. Jakarta: PT Fajar Interpratama Mandiri

Sugiyono,2010. Metode Penelitian Pendidikan (pendekatan Kualitaitf,Kuantitatif dan $R \& D)$. Bandung: Alfabeta

Sugiyono, 2013. Metode Penelitian Pendidikan Pendekatan Kuantitatif, Kualitaitf, Bandung: Alfabeta

Sukardi, dewa ketut. 2008. Pengantar pelaksanaan program bimbingan dan konseling di sekloah edisi revis. Jakarta: PT Rineka Cipta.

Mumpuni, Yekti \& Wulandari, Ari. 2010. Cara Jitu Mengurangi Stres. Yogyakarta: Andi. 